give chase with apparent intent to kill. This was observed on several occasions. Always the jaegers hunted in pairs, flying low at terrific speed. Waders rose in front of them, and one of the little birds was singled out and pursued by both jaegers. Often it was so hard pressed that it was forced to take cover. One was seen to describe a great circle over the lake and finally plunge into a stand of reeds. The jaegers did not pause for a second but immediately climbed at a great pace towards a group of high-flying waders. They concentrated their efforts on a bird that left the group and made for the reeds. It lost altitude rapidly, but before it reached cover pursued and pursuer became one. The distance was too great to see clearly what took place, but it appeared that the sandpiper was caught. While its mate stayed in the air, the lucky jaeger perched on the ground for a minute, long enough to take care of its prize, which likely was swallowed whole.

To see the two dark-winged, whitebellied birds race low over the mud- flats and the water, is an exciting spectacle. They surely are faster than the merlin, and possibly also swifter than the peregrine. In hunting so adroit a flyer as a sandpiper they have a great advantage over the falcons. Instead of stooping at their prospective prey and often overshooting the mark, they are able to follow all its movements. However, as is the case with both merlin and peregrine, by far the greater number of birds chased finally escape, either because the wader makes a smart move and outdistances its pursuer, or because the latter simply gives up and goes looking for an easier target.

In spite of many days of watching in April and May, when countless waders make a stop-over at Beaverhill Lake on their way north, no jaegers have been sighted there during that time. Fall migration through Alberta seems to be fairly regular, however, and may cover a wide front. During September of 1960 I saw a jaeger near Morley, in the foothills west of Calgary.

\title{
FIRST RECORD OF RUFF FOR ALBERTA
}

\section{by Bruce Jones and M. T. Myres}

\section{Museum of Zoology, Department of Biology, University of Calgary}

On May 15, 1967, B. Jones observed four birds that he was at first unable to identify. They were swimming on a slough two miles southeast of Janet, A lberta $\left(50^{\circ} 58^{\prime} 30^{\prime \prime} \mathrm{N}, 113^{\circ} 50^{\prime} 30^{\prime \prime}\right.$ W), about 10 miles east of Calgary. He collected one. Only then did he realize that he had seen four Ruffs (Philomachus pugnax), or more properly two Ruffs and two Reeves.

The bird collected was a male with testis measurement $7 \times 13 \mathrm{~mm}$. indicating a trend to breeding condition. The plumage approximates most closely the type $\mathrm{B}_{2}$ described by Witherby et al (1940). The occipital tufts are black with a purple gloss. The pectoral ruff is white with some grey spots. The underparts are white. The back is pale buff and grey-brown with many feathers having a purple gloss. The skin is No. 145 in the Museum of Zoology of the Department of Biology, University of Calgary.

The four birds seen exhibited somewhat unusual behaviour in that they were swimming on the surface of a slough that was between eight inches and two feet deep at that point, some 15 yards from the shore. They swam in an area of approximately 40 square feet, picking at the surface and occasionally dipping their heads beneath it. During 10 minutes of observation the two males twice suddenly chased each other vigorously in a circle around a fence-post standing in the water. While doing so they displayed their ruffs and quivered their wings for a few seconds. After each occa- 


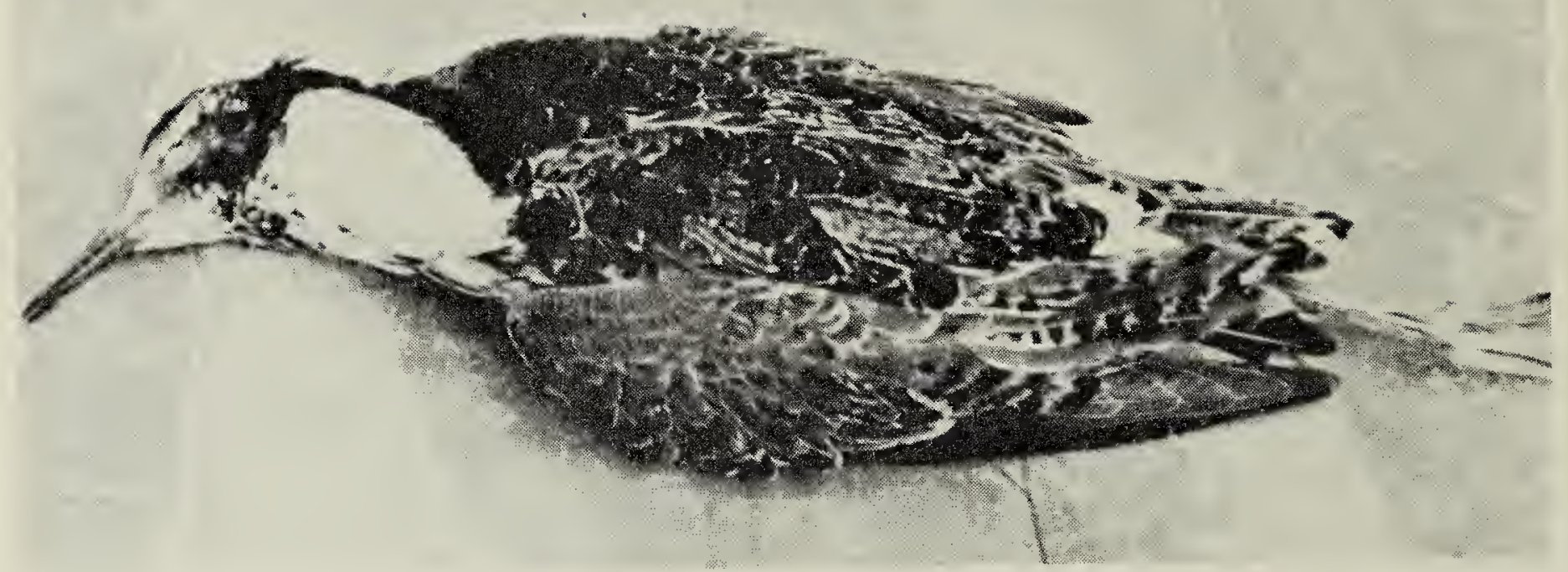

Male Ruff collected May 15, 1967, at Janet, Alberta by Bruce Jones.

sion they resumed feeding.

Prof. W. Ray Salt of the University of Alberta, Edmonton, has confirmed that this is the first record of this species for Alberta.

It is also only the second occasion that Ruffs have been observed in western Canada. On May 8, 1965 one was collected near Regina, Saskatchewan, about 470 miles east of Calgary (Brazier, 1965).

Outside of Alaska, the only records from the western United States are from California, one on March 30, 1962, two in the month of September and one in December (McCaskie 1963). All other records are from the eastern half of the continent: Ontario, Quebec, New Brunswick, Nova Scotia, Minnesota, Wisconsin, Indiana, Ohio, Iowa, New York, Pennsylvania, and the east coast. Peakall (1965) has tabulated the month of observation of nearly 100 Ruff occurrences between 1953 and 1963 (in 1963 alone there were 30 reports). The most frequent months of occurrence are July and August, but there is a smaller spring peak that occurs in May. Peakall suggests that the Ruff may be breeding in North America.

It is interesting to speculate why four Ruffs were seen in Alberta in May, 1967. First, there were two pairs which suggests that they were not accidental vagrants far from home. Second, it is rather remarkable in view of the greater frequency of fall than spring records in North America) that the Saskatchewan record is a May record (Brazier, op. cit.) and that the Minnesota and Wisconsin records (Robbins, 1959; Strubble, 1964) are also May records. None of the westernmost records, therefore, are from the fall except for three from California, the fourth $\mathrm{Cal}$ ifornia record being from March.

The Ruff is a Eurasian shorebird. It has been assumed previously that birds observed in eastern North America have crossed the Atlantic from West Africa to South America but, as Peakall (1965) points out, this would result in more spring than fall observations whereas the reverse is the case. The larger number of fall records is suggestive of small numbers breeding somewhere on the North American continent. Since the fall records are mainly from the eastern states, and the birds are assumed to winter in South America, this would suggest that the North American breeding stock breeds in eastern or central Canada. The May records from Wisconsin, Minnesota, Saskatchewan and Alberta might suggest migrants moving north towards their breeding grounds somewhere in north-central Canada. On the other hand, these may have been displaced migrants from eastern Canada.

Ruffs breed in eastern Siberia, and 
there are several records from Alaska, particularly from St. Lawrence Island in the month of May. This suggested to Gabrielson and Lincoln (1959) that there might be a small breeding population in Alaska. If that were so, the Californian records would be relatively easy to explain, but the east coast records would not be easy to explain unless the species migrated from west to east right across the Continent in the fall, which is not impossible but also not very likely, from southern Alaska.

An examination of the weather maps prior to the Alberta records of May 15, 1967 proves interesting. On May 10 a cold front associated with a depression swept across Alaska. Next day the cold front was moving southeastwards (Fig. 1). On May 13 it was in the southern Yukon, on May 14 (Fig. 2) it passed over northern B.C. and the edge of north Alberta, and on May 15 (Fig. 3) it passed over southern Alberta. It is possible that some Ruffs were carried southeast from Alaska into Alberta, and that they were resting there prior to moving with prevailing winds when seen on May 15. Alternately, the birds may have originated farther south and may have been moving north when grounded, but if so, they would probably already have resumed their journey before May 15.

If we then examine two other May records, those of May 8, 1965 in Saskatchewan and May 23, 1964 in Minnesota, we find that the preceding weather patterns are remarkably similar, differing only in that the warm front occluded the southeastward-moving cold front over a different region in each case - the region where the Ruff record was made.

These three observations tend to suggest that Ruffs reaching the Alaskan breeding grounds from Asia sometimes overshoot them into central Canada and the northern United States when carried by depressions moving eastwards from the Bering Sea. An alternative, but less satisfactory, explanation is that the Alaskan, and even some eastern. Siberian, breeding birds migrate down the west

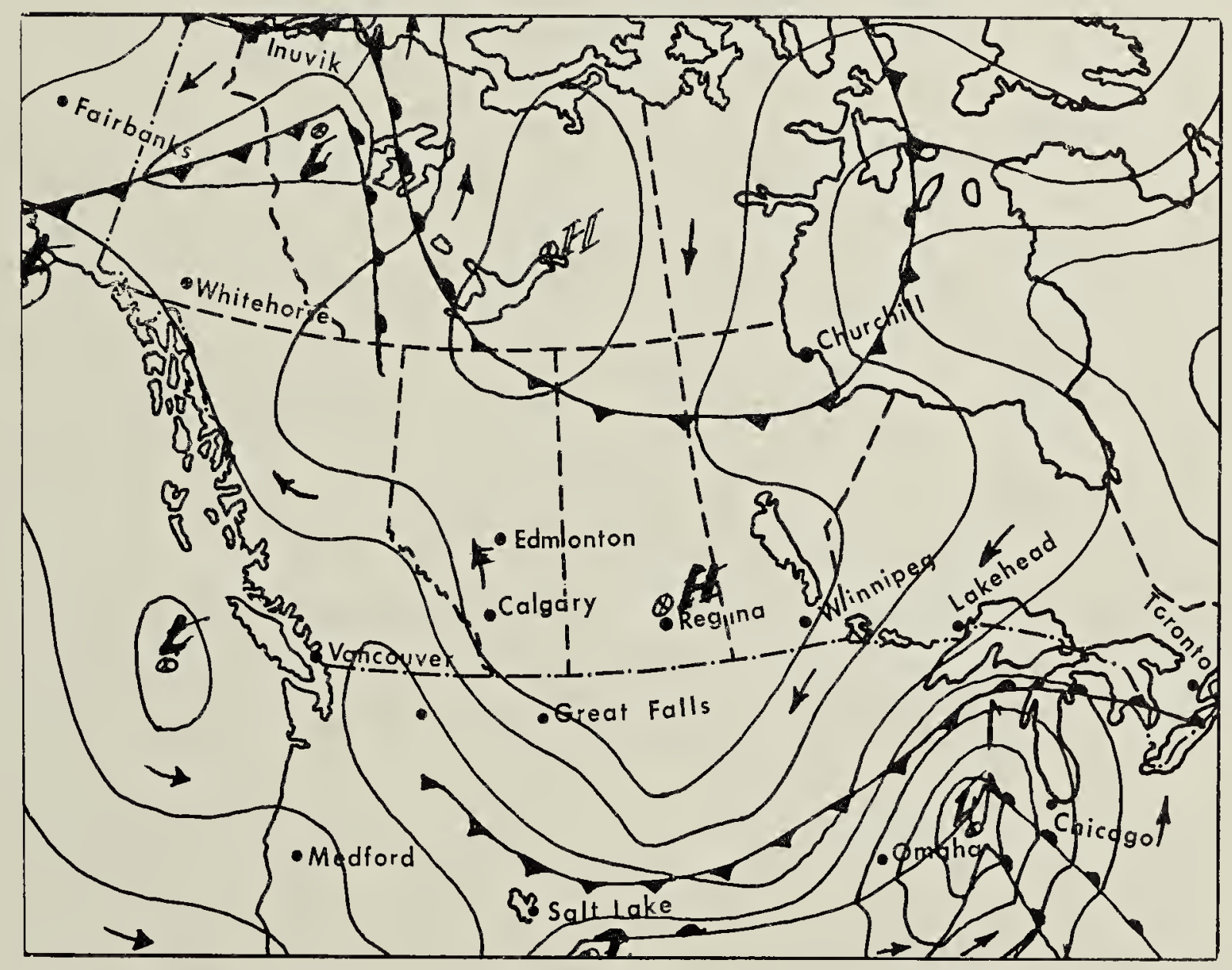

Fig. 1-Weather map for May 11, 1967 showing the cold front associated with the low moving southeast from Fairbanks, Alaska. 


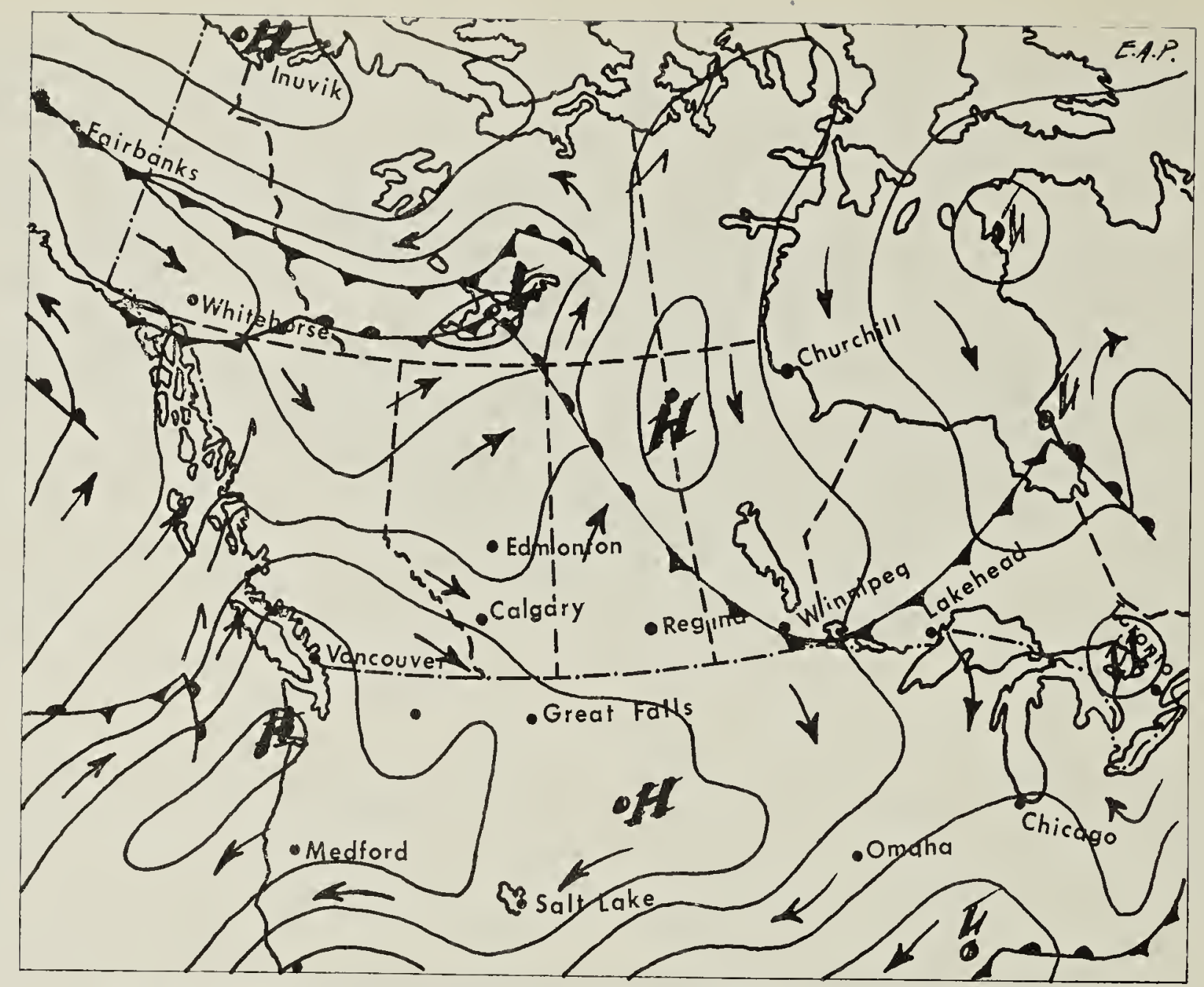

Fig. 2 - Weather map for May 14, 1967 showing the cold front moving southeast from Whitehorse, N.W.T.

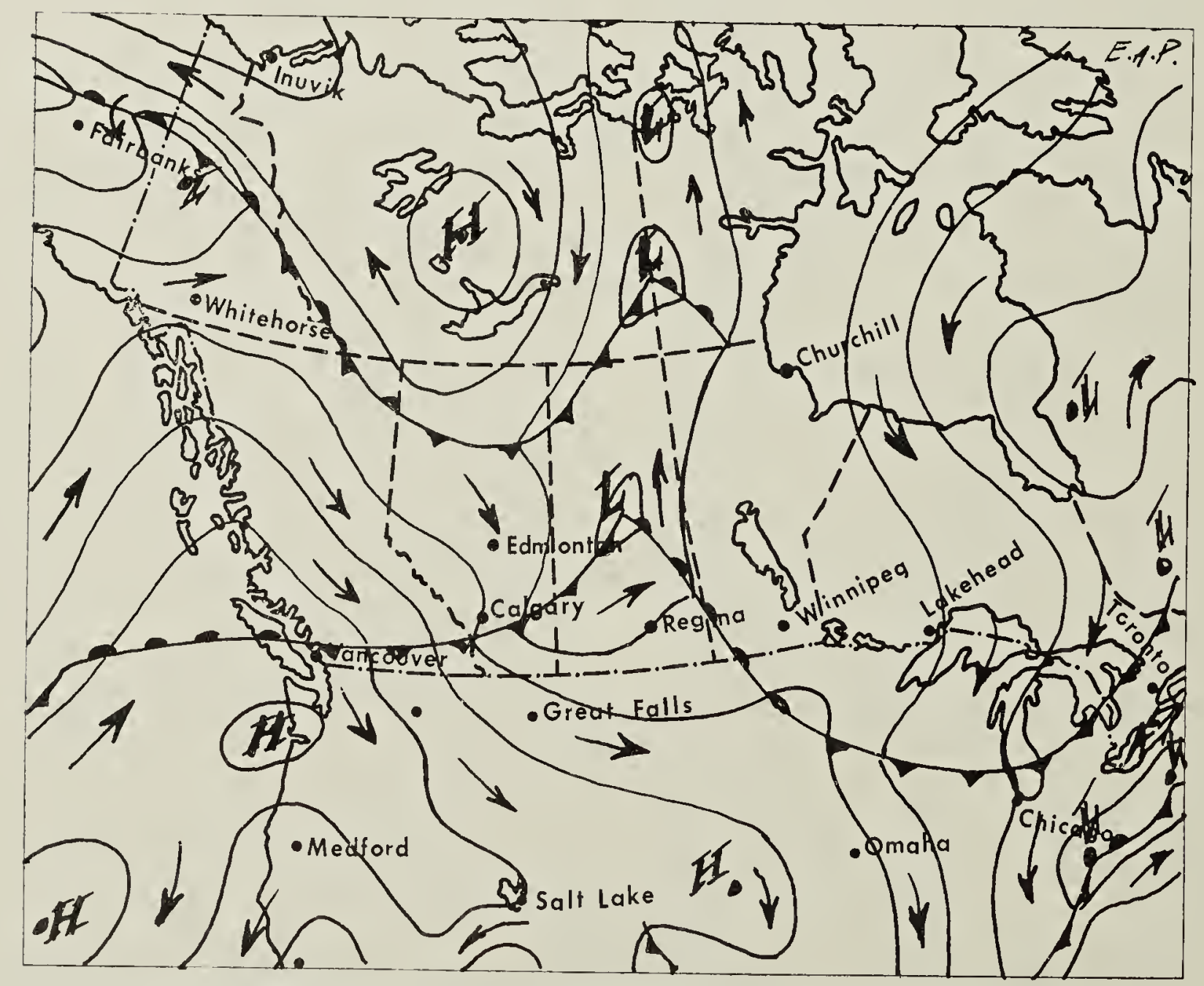

Fig. 3 - Weather map for May 15, 1967 with cold front in the Calgary area and with winds from the northwest. 
coast of America in the fall, and that they may be blown inland from the British Columbia coast by weather systems from the Pacific during the month of May.

The implications are exciting. But nothing is yet certain, particularly since most spring records have been from the eastern half of the continent, which suggests that they are not Alaskan birds. But it will be interesting to analyze future western Canadian records in the light of their possible origin in Alaska. It seems likely that there will be additional May records. We should therefore keep a special watch for this species in future. If there is a North American breeding population outside Alaska of this remarkable bird it may be somewhere in the Canadian north, possibly even in one of the Prairie Provinces. If and when it is found, the location should be kept secret. And, of course, it is also important that as few specimens as possible should be collected, if the postulated breeding population is to flourish. The specimen collected in Alberta was, unfortunately, taken before its identity was realized. But perhaps, since this is a "lek" species, the two females got along happily enough with the remaining male in this instance!

\section{Acknowledgements}

The authors are grateful to the Calgary Weather Office for preparation of the weather maps.

\section{LITERATURE CITED}

Brazier, F. H. 1965. First Saskatchewan record of the Ruff. Blue Jay, 23:120-121.

Gabrielson, I. N., and F. C. Lincoln. 1959. The Birds of Alaska. Stackpole Co., Harrisburg, $\mathrm{Pa}$.

McCaskie, R. G. 1963. The occurrence of the Ruff in California. Condor, $65: 166-167$.

Peakall, D. B. 1965. The status of the Ruff in North America. Wilson Bull., $77: 294-296$.

Robbins, C. S. 1959. A Ruff in Wisconsin. Passenger Pigeon, $21: 73$.

Strubble, E. H. 1964. The Ruff. Loon, 36 :5355.

Witherby, H. F. et al. 1940. The Handbook of British Birds, Vol. IV. Witherby, London.

\section{ANNUAL REPORT OF THE BRANDON JUNIORS' NESTBOX PROJECT}

\section{by Les Rourke, Brandon, Manitoba}

The year 1967 proved to be another successful one for our nest lines. We now have over 1700 nest boxes set out, although only 1200 of these are listed in our field books.

There were two highlights in last year's activities. The first highlight was the great increase of Mountain Bluebirds, with the species more than doubling its former high mark of 79 nests.

The other item of importance was the finding of a hybrid male bluebird (Mountain X Eastern) which had both a Mountain Bluebird and an Eastern

\section{Species}

Common Goldeneye

Tree Swallow

Eastern Bluebird.

Mountain Bluebird

Eastern Bluebird X Hybrid male

Mountain Bluebird X Hybrid male

(same male as above)

House Sparrow

March, 1968
Bluebird mate. From the first of these two nests, six young were successfully hatched. This is reported to be the first example of a wild hybrid in the thrush family, let alone a successful back cross in the bluebird family in North America. A full report is in preparation.

Last summer we moved a number of nest boxes to new locations, and over 100 new boxes were built and set out. For 1968 we plan to build and set out over 100 more, some of these being replacements. Here are the totals of nests checked in 1967.

\section{Total nests}

1 (perhaps more)

$1000+$

.55 first broods

160 first broods

1 (nest unsuccessful)

1 (nest successful)

a few 